\title{
Measuring Quality of Service of Rural Banks in Oyo State
}

\author{
Adeleke, MosesSolagbade (Ph.D) \\ Department of Business Education,EmmanuelAlayandeCollege of Education, Oyo, Lanlate Campus
}

\begin{abstract}
This study investigates the effect of service quality measures of rural bank patrons on the rural banks' performance. From the data collected from four hundred and eighty sample representatives from the study area from the rural communities of Oyo State, it was found that the overall service quality assessment indicates that only service quality of commercial banks operating in the rural areas could not meet rural banks' customers demand. The study further indicates that service quality has a significant effect on financial sustainability of the rural banks but do not have significant effect on the bank coverage in the rural banks.
\end{abstract}

Keywords: Rural Banks, Microfinance, Financial sustainability, Coverage, Loan portfolio, Bank patrons

\section{Introduction}

The military junta administration of General Ibrahim Babangida laid the foundation of the present Microfinance Institution in Nigeria in 1990. It was this singular policy initiative that made many communities to set up their own Community Banks that later transformed into the present day Micro Finance Banks that exist in most rural communities in Nigeria today. Without this, the rural banking policy of the Central Bank of Nigeria would still be hard for many commercial banks to follow to open branches in rural sector as expected as a result of so many factors. Among these factors that inhibit the opening up of rural financial market as contained in Report No 26030 (2003) include:

i. Low population density, small average loans, and low household savings increase the transaction costs per monetary unit of financial intermediation.

ii. Lack of infrastructure (communications, electricity, transportation, etc.) and social services (education, health, etc.) and low integration with complementary markets result in highly fragmented financial markets that involve high costs of overcoming information barriers and limit risk diversification opportunities.

iii. Seasonality of agricultural production and susceptibility to natural disasters (such as flood, drought, and disease) heighten the probability of covariant risks (in prices and yields) and add to the risks and costs of rural financial intermediation.

Before now, many rural local government areas or divisions or regions in the country either have a branch of a bank (without any other branch to compete with) or none at all. Where there is a branch, the branch operated on complete monopolistic market thereby driving the supposed banking culture that should be enhanced back to pre-civilisation era of burying money inside pot or bamboo tree to be securely laid inside sand or cave as a result of poor banking services received from the existing bank branch that is operating without competition. The situation also made the rural dwellers to have erroneous belief that commercial banking services are for government workers or avenue for government to tax individual and this conception makes rural dwellers to develop a strong positive loyalty attitude towards patronising informal micro finance market that are being operated by "SUSU" (market/daily contributors) for their financing and investment needs. Patronising "SUSU" dominated informal micro finance market relieves them of stress commonly associated with conventional banking services as "SUSU" operators meet them at their place of business or residence. The service time is customers oriented with high level of custom made confidentiality without customers queuing up for service for an unending period that often makes them lose income as a result of patronising conventional and micro finance banks.

Though, the loan portfolio of "SUSU" operators is usually small, but is custom made with high interest rate. The conventional as well as microfinance bank loan is incomparably large but dotted with much paper work, which does not suit the high illiterate culture of the rural economy. These banks also have lending ability of long term but in most cases secured with assets or any form of collateral which many of the rural people that are unemployed, women and farmers could not provide.

Taking service time, waiting time, perception and coverage as well as financial sustainability of rural banks together, they determine the quality of services they provide in the hands of rural banks' patrons as they access the banks for savings and withdrawals, and loan portfolio. With this, it becomes interesting to measure the quality of services rural banks in Oyo State with particular reference to microfinance banks that bring banking services to the door posts of rural dwellers.

In carrying out the above, an attempt will be made to gain an insight into the effects of service quality in rural banking outreach and financial sustainability with a view of complementing the current literature on 
rural banking and financial market in Nigeria. In order to determine what the service quality of the rural banking, this study will provide answer to:

i. How do rural bank patrons see service quality of the rural banks in Oyo State?

ii. To what significant extent does service quality of rural banks in Oyo State affects the rural banking performance?

The answer to the above will form the basis of the study recommendation that can impact on the service quality improvement and sustainable quality practice that will shape up rural banks for better service delivery.

As this study will be enquiring into the effect of service quality of rural banks on their performances, the basic hypothesis of the study can thus be stated as:

That service quality of the rural banks in Oyo State can reduce the rural banking performance in the state.

The negative form of this proposition has no special significance and is chosen only for convenience. This hypothesis can be broken down into one easy to handle and verify proposition as follows:

$\mathrm{H}_{01}$ There is no significant effect of service quality of rural banking on rural banks performance

\section{Theoretical Framework}

Service quality is the competence of a product or service to carry out its specified tasks (Ennew et al., 1993).Parasuraman, Berry and Zeithaml (1991) in their serqualmodel it was stressedthat customers assess service quality by comparing their expectations of service (SE) with their perception of services (SP) received. Service quality should be aimed at the needs of the consumer, present andfuture. The service quality occurs when service expectations (SE) are met or exceeded, but otherwise servicegap exists (Adeleke, 2012)

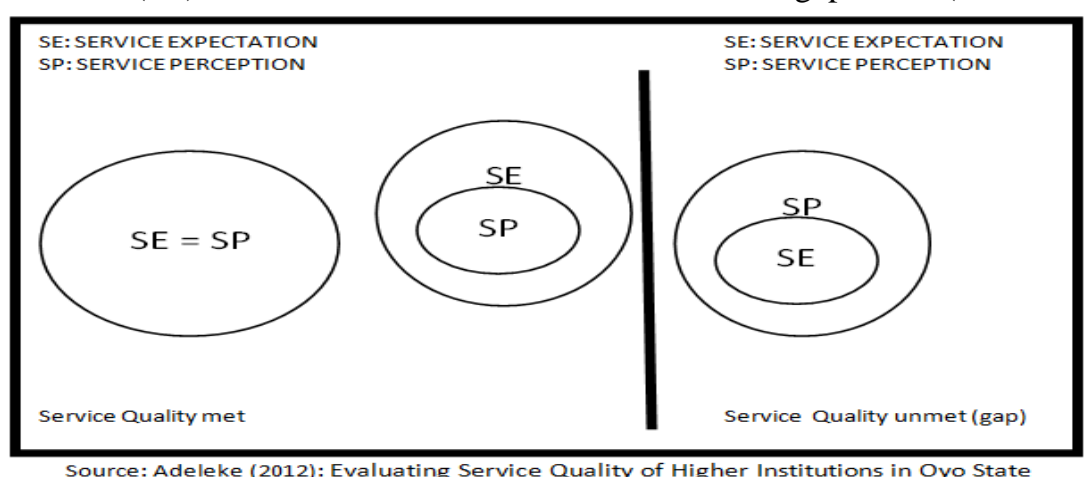

Fig. 1: Mathematical Model of Evaluating Service Quality

Service quality of individual can never be the same, but the average of aggregate of various service quality expression can lead us to a fairly expressed conclusion that there is or no service gap existing in the service unit performance of an entity. A service entity that has more than one service point, the service quality of each point can never be the same also. To describe the service quality of such entity requires an assessment of expression of patrons of each or all service points in that entity. If there is some improvement in service quality, customer satisfaction also increases and vice-versa. This of course impacts the bank coverage and financial sustainability.

In a competitive banking service world of today, successful banking outfits must be able to satisfy their customers in order to attract new customers and retain theloyalty of both old and new customers that will impact rightly on their financial sustainability and coverage (see Arora, 2005). Zhou (2004) and Lopez et al., (2007) examined the impact of service quality dimensions on customer satisfaction and found that service quality was the key determinant of customer satisfaction and reliability was the most important dimension of service quality.

Banking services are feasibly providing access to savings and withdrawal, fund transfer, Loan services and advisory/consultancy services. These are core services people believed banks provide. The invisible services such as good cooling system, environmental services, confortable furniture, timelines and good human relationship are also part of the banking services customers sought impliedly from a bank. The quality of both core and auxiliary services determine the service quality in a bank patron's hand. Some customers may because of the poor quality of what aretermed auxiliary services of banks get discouraged from patronising a bank regardless of the suitability of its core banking services. To measure the service quality of banks, it becomes inevitable to look at the core as well as auxiliary services to determine the type of satisfactions bank customers have as they patronise these banks. From the literature, copious evidences exist to affirm the fact that customers' satisfaction is a good measure of service quality. However, how we measure the customers' satisfactions is provided by Parasuraman, Berry and Zeithaml (1991). In addition, Johnson (1997), commitment, attentiveness, friendliness, care and courtesy are found to be significant factors influencing customer satisfaction. These issues 
are added indices of service quality bank staff provided to bank customers as they relate with the banks. To measure customers' satisfaction, (Kangis and Vouklatos, 1997 and Arasli et al., 2005), Kangis and Vouklatos (1997) in their study compared the expectations and perceptions of service quality among different groups of customers. The collapsing tree model of Adeleke (2012) measures two distinct aspects of any given service point with the scores of customers on service quality as it affects the staff and the facilities being used. In the model, sought attributes of satisfactions by bank customers are provided as it affects quality value bank staff represents as well as banks' facilities to provide needed service quality that will impact on banks' performances as evidenced by its coverage and financial sustainability thus:

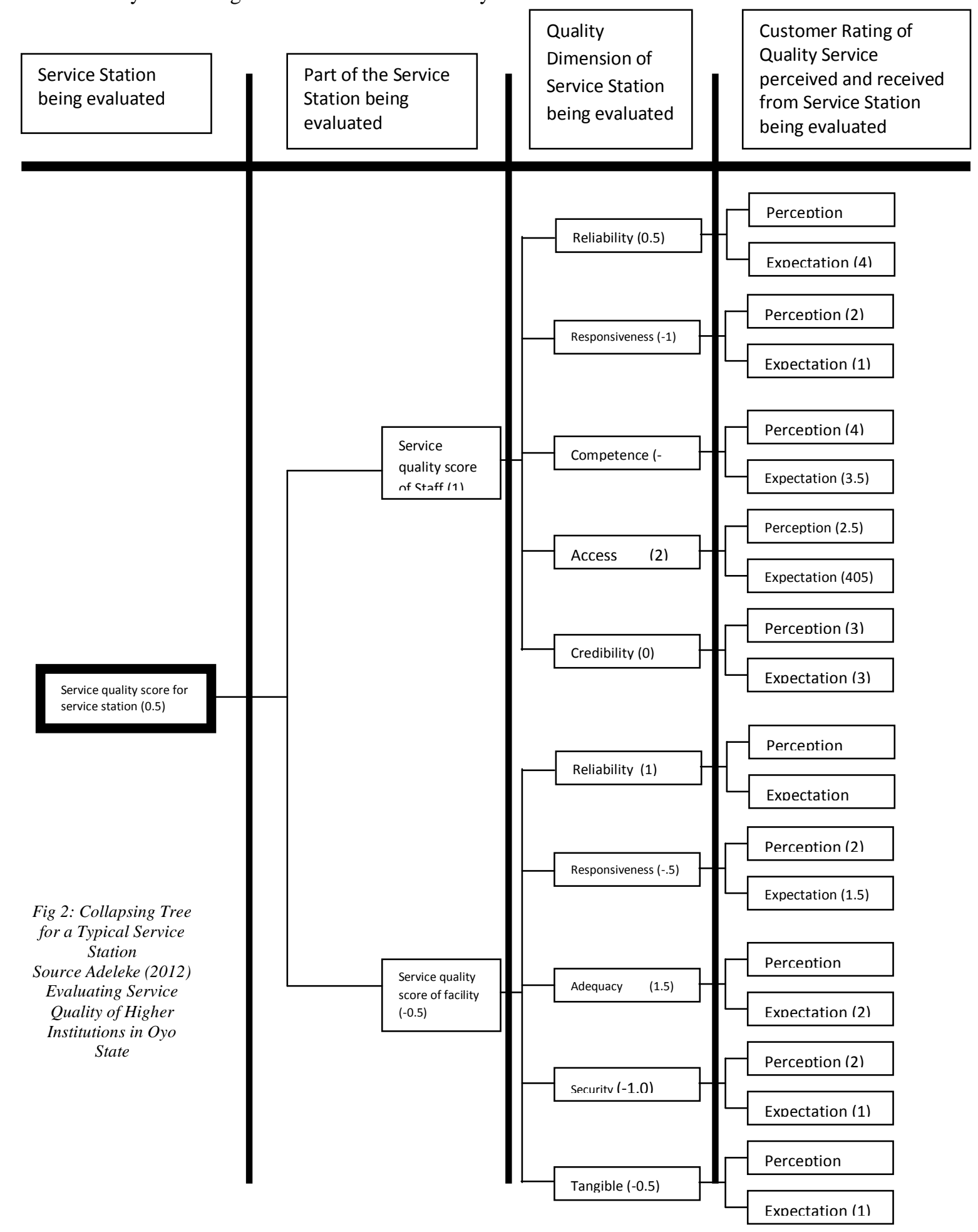


With the aid of collapsing tree as shown in fig. 2, theorganization is readily armed with information on service quality gaps and takes appropriate actions as needed. And lastly information on levels of customers can help the management to best know what customers actually expect from particular service stations. As shown in fig 2, service quality score for staff is positive (1) but staff responsiveness and competence scores are negative, then managers need to turn on their search light for solutions on these attributes and initiate improvement program on staff rate of responsiveness and competence that customers want. In the same vein, facility score is negative; how facility respond to demand being placed on it is a major concern; likewise its security and tangibility of service being produced from it must be improved upon. (SeeAdeleke, 2012)

From the foregoing, the customers' expression on bank staff and facilities define the service quality of the banks. ATM, Internet banking as services are powered by different services unknown to customers. Since customers do not have direct relationship with bank staff they are best regarded as facilities. Therefore the position the literature is both perception and expectation of bank patrons from bank staff and facilities form the basis of opinion patrons have on the different services' banks provide.

From the review of the literature, we may construct a model as shown below to measure the effects of service quality on bank performance. From the fig. 3, there are some measures of bank performance that are highlighted. The outcome of these measures is part of the reasons why commercial banks are reluctant to have rural branch as directed by central bank as they indicate lack of financial institution capacity of the rural areas. But the microfinance banks operating and owned by members of the rural community find their arrival easier in the rural areas to provide access to savings and withdrawal ofliquid cash, loan, and transfer of fund as well as advisory/consultancy services that can assist the rural micro entrepreneurs to succeed.

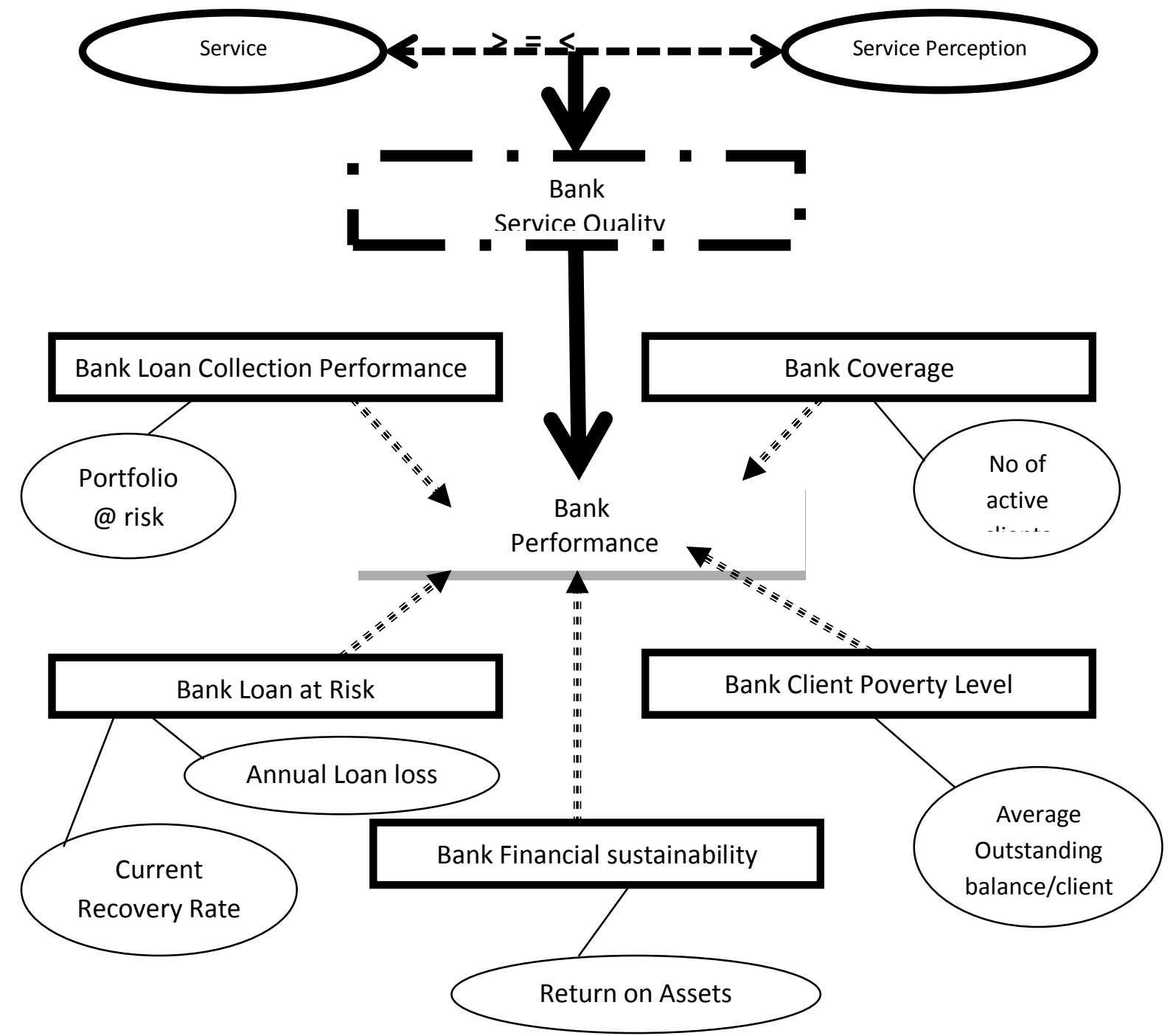

Fig 3: Impact model of Bank Patrons' Service Quality Assessment on Bank Performance Source: Self Developed by author 
In conclusion, out of the five highlighted bank performance measures, and the banking services rural banks offer, service quality measures have a kind of impact. The literature reviewed so far indicated impact of bank service quality on bank coverage and financial performance. It is also possible for service quality to impact bank loan collection and loan at risk with accelerated interest rate that are attached to unending monetary policy rate regime of central bank of Nigeria in her bids to checkmate inflation in the economy. This and other rural bank management grey areas may inhibit loan collection rate and thereby putting the bank loan at risk than ever imagine.

\section{Research Methodology:}

i.The Study Area: There are thirty three local government areas in Oyo State with about two -third of it in the rural areas. Out of this two third, six local government areas were selected for this stud, which comprises of Ibarapa East, Ibarapa Central, Ibarapa North, Itesiwaju, Iwajowa and Kajola Local Government Areas. From these local government areas, there are seven rural branches of five commercial banks, thirteen Micro Finance Banks and two agricultural development bank branches at the beginning of this century. But as at the time of this research work four micro finance banks and two commercial banks have wound up.

Fig. 4:

The Study Area in the Context of Oyo State

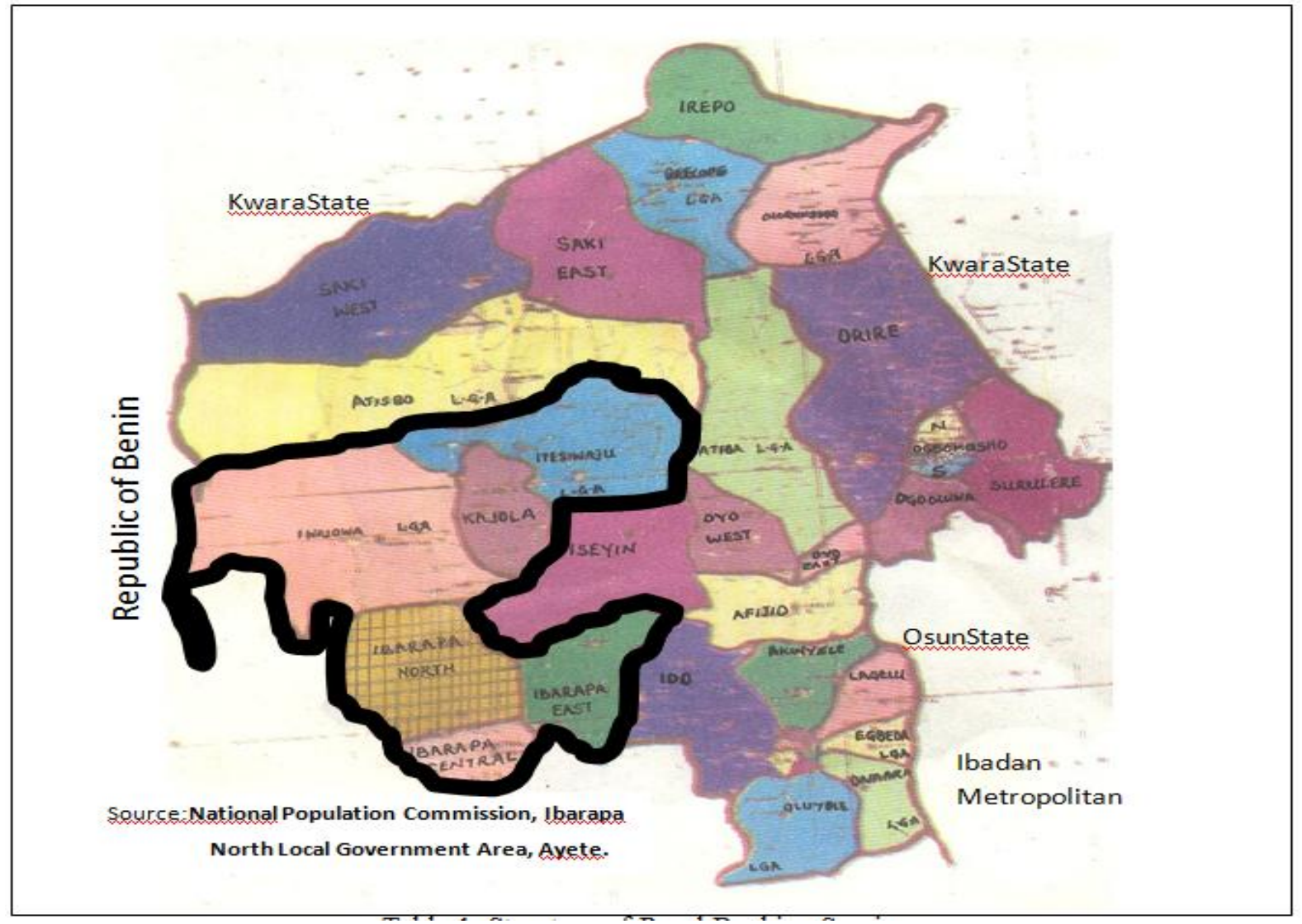

Table 1: Structure of Rural Banking Services

\begin{tabular}{|c|c|c|c|c|c|c|c|c|}
\hline \multirow[b]{2}{*}{ Local Government Area } & \multicolumn{2}{|c|}{$\begin{array}{c}\text { Micro Finance } \\
\text { Bank }\end{array}$} & \multicolumn{2}{|c|}{$\begin{array}{l}\text { Commercial } \\
\text { Bank }\end{array}$} & \multicolumn{2}{|c|}{$\begin{array}{c}\text { Develop- } \\
\text { mental Bank }\end{array}$} & \multicolumn{2}{|c|}{ Total } \\
\hline & $\begin{array}{l}\text { Before } \\
2012\end{array}$ & 2012 & $\begin{array}{l}\text { Before } \\
2012\end{array}$ & 2012 & $\begin{array}{l}\text { Befor } \\
\text { e } \\
2012\end{array}$ & 2012 & $\begin{array}{l}\text { Before } \\
2012\end{array}$ & 2012 \\
\hline Ibarapa East & 3 & 3 & 2 & 1 & & & 5 & 4 \\
\hline Ibarapa Central & 1 & 1 & 2 & 2 & 1 & 1 & 4 & 4 \\
\hline Ibarapa North & 3 & 2 & & & & & 3 & 2 \\
\hline Iwajowa & 2 & 2 & & & 1 & 1 & 3 & 3 \\
\hline Kajola & 2 & 1 & 2 & 2 & & & 4 & 3 \\
\hline Itesiwaju & 2 & 0 & 1 & 0 & & & 3 & 0 \\
\hline Total & 13 & 9 & 7 & 5 & 2 & 2 & 22 & 16 \\
\hline
\end{tabular}

Source: Field Survey Data, 2012 
ii.Data Collection: Data for the study were derived from primary sources obtained through a structured questionnaires administered on bank patronsand banks from each of the local government areas. Data collected were responses on service quality gap on likert scale of 5 points ranges from Unmet service quality (-1) to Met service quality (2) by bank patrons and effect of service quality on bank performance from bank managers. Likewise data on gender, educational status/level, type of occupation and bank customer type were also collected. Random sampling method was employed in selecting 50 respondents from each of the local government areas.

iii.Method of Data Analysis: Descriptive and inferential methods were used to analyse the data collected. The descriptive method includes the use of bar chart, pie chart, and tables The F-statistic, Pearson Correlation were used to ascertain the statistical significance of the variables in the specified model.

iv.Model Specification:

a. Service Perceived and Expected Model

QM: $\mathrm{SE}>=\mathrm{SP}$

QG: $\mathrm{SE}<\mathrm{SP}$

Where QM = Quality Met $\quad$ SE = Service Expected

$\mathrm{QG}=$ Quality GapSP = Service Perceived

b. Regression Model

$\mathrm{Y}=\beta_{0}+\beta_{\mathrm{n}}$

Where $\mathrm{Y}=$ Bank Performance

$\mathrm{B}_{\mathrm{o}}=$ coefficient of the regression (if the coefficient is negative, then bank performance is poor otherwise, good)

$\beta_{\mathrm{n}}=$ Bank service quality

III. Results And Discussions

Table 2: Analysis of Biographic Attributes of Respondents

\begin{tabular}{|c|c|c|c|c|c|c|c|c|}
\hline \multicolumn{3}{|c|}{ Gender } & \multicolumn{3}{|c|}{ Education } & \multicolumn{3}{|c|}{ Occupation } \\
\hline Type & $\mathbf{F}$ & $\%$ & Type & $\mathbf{F}$ & $\%$ & Type & $\mathbf{F}$ & $\%$ \\
\hline Total & $\begin{array}{l}229 \\
251\end{array}$ & $\begin{array}{l}47.71 \\
52.29\end{array}$ & $\begin{array}{l}\text { Primary } \\
\text { Secondary } \\
\text { Tertiary }\end{array}$ & $\begin{array}{l}189 \\
165 \\
126\end{array}$ & $\begin{array}{l}39.37 \\
34.38 \\
26.25\end{array}$ & 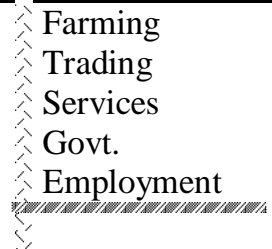 & $\begin{array}{l}197 \\
112 \\
115 \\
56 \\
\\
480\end{array}$ & $\begin{array}{l}41.04 \\
23.33 \\
23.96 \\
11.67 \\
100\end{array}$ \\
\hline \multicolumn{3}{|c|}{ Banker } & \multicolumn{3}{|c|}{ Bank Account } & \multicolumn{3}{|c|}{ Bank service } \\
\hline Type & $\mathbf{F}$ & $\%$ & Type & $\mathbf{F}$ & $\%$ & Type & $\mathbf{F}$ & $\%$ \\
\hline $\begin{array}{l}\text { Commercial } \\
\text { Microfinance } \\
\text { Developmental }\end{array}$ & $\begin{array}{l}94 \\
263 \\
123\end{array}$ & $\begin{array}{l}19.58 \\
54.79 \\
25.68\end{array}$ & $\begin{array}{l}\text { Savings } \\
\text { Current }\end{array}$ & $\begin{array}{l}423 \\
57\end{array}$ & $\begin{array}{l}88.13 \\
11.87\end{array}$ & $\begin{array}{l}\text { Savings \& } \\
\text { Withdrawal } \\
\text { Loan } \\
\text { Advisory } \\
\because \\
\therefore\end{array}$ & $\begin{array}{l}480 \\
212 \\
123\end{array}$ & $\begin{array}{l}100 \\
44.17 \\
25.63\end{array}$ \\
\hline
\end{tabular}

From table 2, there are four hundred and eighty sample representatives for the study; $47.71 \%$ of them are male while the rest are female. Majority of these people have basic primary education, are farmers, patronise microfinance banks with savings accounts and only about $44.17 \%$ enjoyed loan facilities. The implication of this finding is in the rural areas of Oyo State bank patrons have low business and financial skills as majority of the respondents keep savings accounts and less than half of them go for loan and advisory services. In addition, poor rural bank management quality may also be responsible for this. 
Fig.5: Bar Chart of Staff, Facility and Loan Process Service Quality of Sampled Rural Banks in Oyo State, Nigeria

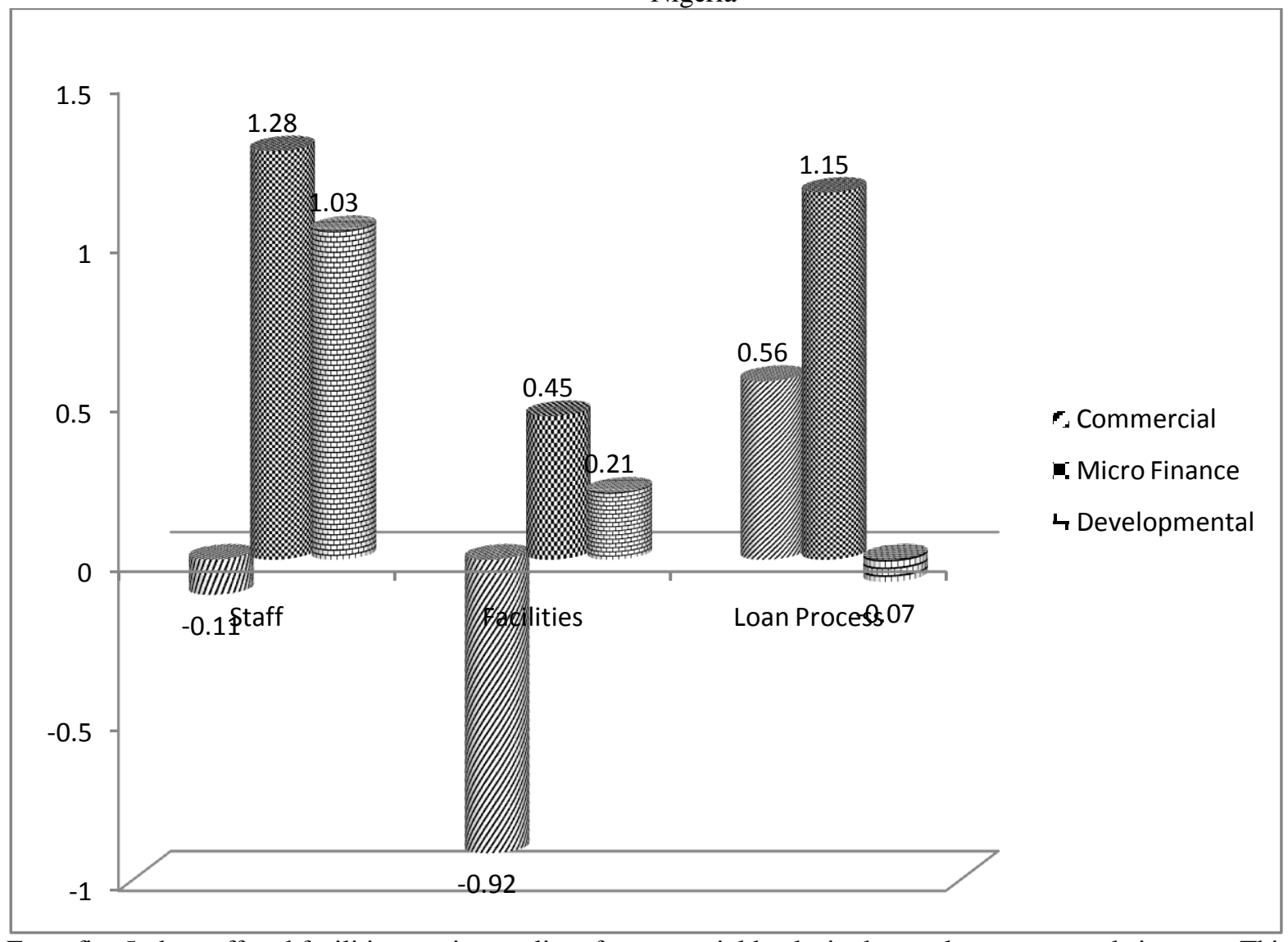

From fig. 5, the staff and facilities service quality of commercial banks in the rural areas are not being met. This may be as a result of poor rural financial capacity to sustain commercial banks existence. The staffing positions are appalling to handle demand being placed on the banking capacity especially during the peak period of banking hours. Long waiting lines, prolonged service time and unruly behaviour of cashiers as a result of terrified but unending queue for service in their fronts make customers unsatisfied with their services. Likewise the poor service quality of equipment may also be due to the basic believe that rural banks are not financially viable thereby forcing the management at the headquarters pushing substandard facilities to rural banks for their operations. In addition, network failure of service providers that powered the banks do make the computer facilities to work beyond level of tolerance. To cap it all, commercial banks are majorly being used by government workers and big farms in the rural areas and these banks are always congested especially during the salary pay time. Micro finance and agricultural development banks do face this type of demand and customers. The service quality gap for both micro finance and agricultural development banks simply tells us that most staff and facilities are not needed for their operations (see fig. 5). This tells much on their financial sustainability as many of the rural micro finance banks are operating under financial difficulty to declare dividends at least once since their inceptions. From Fig. 6, the service gap of micro finance banks is a very high positive gap, which means that the micro finance banks exceed customers 'expectations through staff, facilities and loan processing cycle time. The implication of this is the cost of operation associated with this level is high.. This is a clear indication of weak institution capacity on the part of micro finance banks operating in the rural areas and also, it is a clear indication that micro finance bank is highly needed as a strong participants in the rural financial market not as profit making entity. 
Fig. 6: Trend Analysis of Service Quality Gap of Sampled Rural Banks in Oyo State

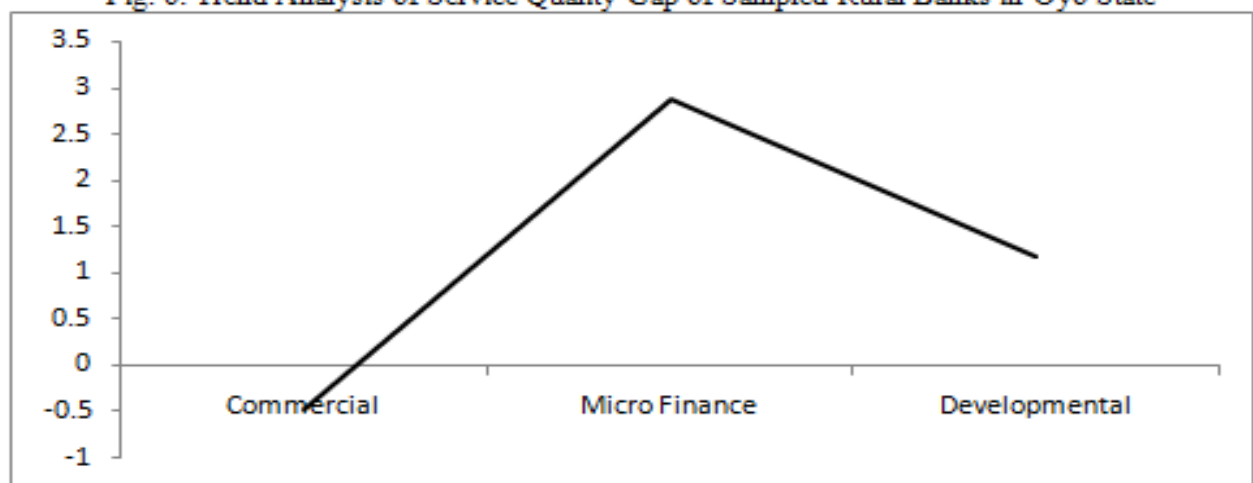

Fig. 7: Bar Chart of Sampled Rural Banking Performance Rating in Oyo State

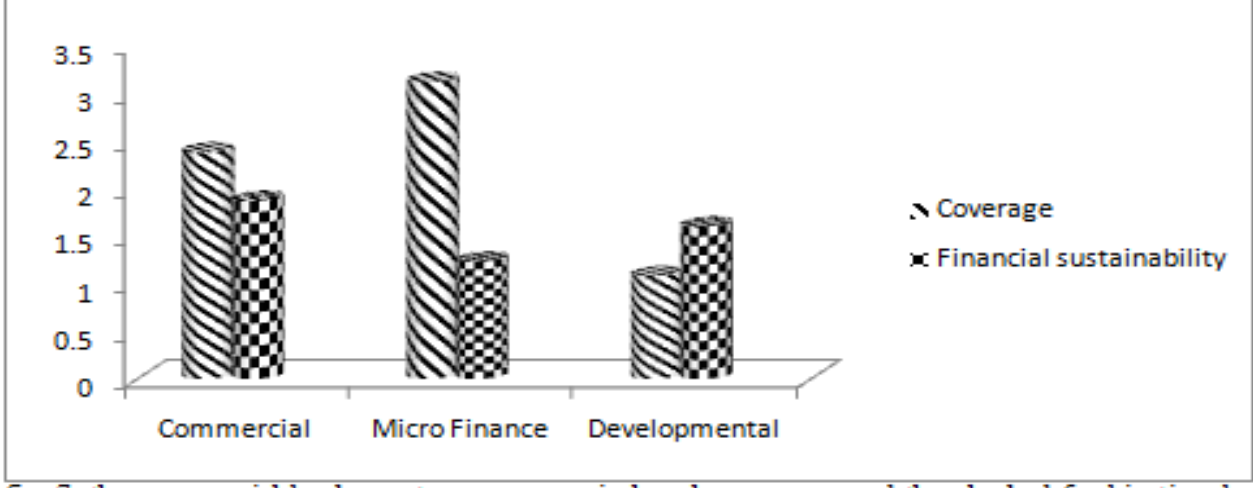

From fig. 7, the commercial banks customers are majorly salary earners and they look forime busines people unlike microfinance bank that looked for core rural people that needs financial assistance. But the low rating of their financial sustainability also compel them to gun for the same class of customers with commercial banks in addition to the primary class of customers they serve. The primary class of customers they serve consist of poor, women and excluded customers of commercial banks whose income are very low compared to the class of customers commercial banks served. They (microfinance banks) access the rural community better but the financial sustainability is a big problem to be solved. Agricultural Development banks served farmers primarily and most of these farmers have poor banking habit; their class of customers are fairly restricted, and their financial sustainability is not a problem as the primary aim is not for profit.

Table 3a: Regression Results of the Effects of Rural Banking Service Quality on Banks Performance

\begin{tabular}{|l|r|r|r|r|r|}
\hline $\begin{array}{c}\text { Performance Issues } \\
\text { (Y) }\end{array}$ & \multirow{2}{*}{$\mathrm{R}^{2}$} & \multicolumn{2}{|c|}{ (sig. Value) } & \multirow{2}{*}{$\begin{array}{c}\left(\beta_{0}\right) \\
\text { Constant }\end{array}$} & $\begin{array}{c}\left.\text { ( } \beta_{\mathrm{x}}\right) \\
\text { Staff } \\
\text { Service Quality }\end{array}$ \\
\cline { 3 - 4 } & & $\mathrm{F}$ & $\mathrm{t}$ & & 0.077 \\
\hline Bank Coverage & 0.004 & 0.960 & 0.297 & 2.330 & -0.275 \\
\hline Financial Sustainability & 0.984 & 0.081 & 0.012 & 1.825 & \\
\hline
\end{tabular}

Table 3b: Regression Results of the Effects of Rural Banking Service Quality on Banks Performance

\begin{tabular}{|c|c|c|c|c|c|}
\hline \multirow{2}{*}{$\begin{array}{l}\text { Performance Issues } \\
\text { (Y) }\end{array}$} & \multirow[t]{2}{*}{$\mathrm{R}^{2}$} & \multicolumn{2}{|c|}{ (sig. Value) } & \multirow{2}{*}{$\begin{array}{c}\left(\beta_{0}\right) \\
\text { Constant }\end{array}$} & \multirow{2}{*}{$\begin{array}{c}\left(\beta_{\mathrm{x}}\right) \\
\text { Facility } \\
\text { Service Quality }\end{array}$} \\
\hline & & $\mathrm{F}$ & $\mathrm{t}$ & & \\
\hline Bank Coverage & 0.003 & 0.964 & 0.114 & 2.393 & 0.072 \\
\hline Financial Sustainability & 0.983 & 0.08 & 0.009 & 1.599 & -0.278 \\
\hline
\end{tabular}

Table 3c: Regression Results of the Effects of Rural Banking Service Quality on Banks Performance

\begin{tabular}{|c|c|c|c|c|c|}
\hline \multirow{2}{*}{$\begin{array}{c}\text { Performance Issues } \\
\text { (Y) }\end{array}$} & \multirow[t]{2}{*}{$\mathrm{R}^{2}$} & \multicolumn{2}{|c|}{ (sig. Value) } & \multirow{2}{*}{$\begin{array}{c}\left(\beta_{0}\right) \\
\text { Constant }\end{array}$} & \multirow{2}{*}{$\begin{array}{c}\left(\beta_{\mathrm{x}}\right) \\
\text { Loan Process } \\
\text { Service Quality }\end{array}$} \\
\hline & & $\mathrm{F}$ & $\mathrm{t}$ & & \\
\hline Bank Coverage & 0.974 & 0.112 & 0.022 & 1.365 & 1.671 \\
\hline Financial Sustainability & 0.118 & 0.777 & 0.098 & 1.701 & -0.130 \\
\hline
\end{tabular}


Table 3d: Regression Results of the Effects of Rural Banking Service Quality on Banks Performance

\begin{tabular}{|c|c|c|c|c|c|}
\hline \multirow{2}{*}{$\begin{array}{l}\text { Performance Issues } \\
\text { (Y) }\end{array}$} & \multirow[t]{2}{*}{$\mathrm{R}^{2}$} & \multicolumn{2}{|c|}{ (sig. Value) } & \multirow{2}{*}{$\begin{array}{c}\left(\beta_{0}\right) \\
\text { Constant }\end{array}$} & \multirow{2}{*}{$\begin{array}{c}\left(\beta_{\mathrm{x}}\right) \\
\text { Service Quality }\end{array}$} \\
\hline & & $F$ & $\mathrm{~T}$ & & \\
\hline Bank Coverage & 0.138 & 0.758 & 0.263 & $2-136$ & 0.203 \\
\hline Financial Sustainability & 0.964 & 0.121 & 0.014 & 1.714 & -0.120 \\
\hline
\end{tabular}

From the statistical evidence in table $3 \mathrm{a}-\mathrm{c}$, the rural banks' coverage level of achievement is not due to the service quality of both bank staff and facilities. This may be so because majority of the salary earners do collect their salaries through banks. But bank loan process service quality has significant effect on banks' coverage. Loan process service quality has little explanation on financial sustainability performance but significant effect on bank coverage performance. Likewise Bank staff and facility service quality have significant effect on financial sustainability of rural banks. The overall effect of Bank service quality is significant on financial sustainability of rural banks than its coverage level performance (see table 3d.). Therefore the conclusion of this study is bank service quality has significant effect on financial sustainability of rural banks than rural banks' coverage.

\section{Summary, Recommendation and Conclusion}

The study used four hundred and eighty sample representatives that patronise five commercial banks, two agriculture developmental banks and nine microfinance banks from the sampled local government areas. The majority of the respondents are female, with at least primary school type of education, engages in farming, patronise microfinance banks; keeps savings account and $44.17 \%$ of them enjoy loan facilities. Service expected from microfinance banks and agricultural development banks are not just meeting some customers' needs but exceeding them thereby increasing its reputation.But services from commercial banks has negative quality score, which shows these banks are just exist in the rural areas to meet Central Bank of Nigeria's directive on rural banking and also to minimise cost. From the analysis of responses from bank managers on their banks' performance, it was noted that microfinance banks outperformed all banks on coverage but commercial banks outperformed others on financial sustainability. This study also established that staff and facility service quality has significant effects on financial sustainability of the rural banks and loan processing cycle time affects the bank coverage ability in the rural areas.

Based on the findings of this study, the commercial banks management should put in place improvement methods that will ease the patrons' suffering in receiving services especially during the peak period. The quality of the microfinance banks services should also be worked upon as to impact positively on the financial sustainability of the banks.

\section{Limitation of the Study}

There are few limitations of this study. In the first instance, the study area needs to be increased from the present six local government areas upward in the future for the findings of this study to have a general acceptability. And if possible large size of respondents should be used for each occupation class in the rural areas.

\section{Reference}

[1]. Adeleke, M. S. (2012): Evaluating Service Quality of Higher Institutions in Oyo State International Organization of Scientific Research (IOSR/BM) 2278-487X Vol. 1 Issue 3 IOSR0107JBM June 2012, pp. 01 - 07 Available http://iosrjournals.org/journals/iosr$\mathrm{jbm} /$ pages/v1i3.html

[2]. Arasli, H., Katircioglu, S. T. and Smadi, S. M. (2005), “A Comparison of Service Quality in Banking SectorSome Evidence from Turkish and Greek Speaking areas in Cyprus", International Journal of Bank Marketing, Vol. 23 (7), pp. 508-526.

[3]. Arora S. (2005), Marketing of Financial Services, Deep and Deep Publications Pvt. Ltd., New Delhi, pp.90-110.

[4]. Johnson, R. (1997), "Identifying Critical Determinants of Service Quality in Retail Banking: Importance and Effect", International Journal of Bank Marketing, Vol. 15 (4), pp. 111-116.

[5]. Kangis, P. and Voukelatos (1997), "Private and Public Banks: A comparison of Customer Expectations and Perceptions", International Journal of Bank Marketing, Vol. 15 (7), pp. 279-287.

[6]. Lopez, J., Hart, L. K. and Rampersad, A. (2007), "Ethnicity and Customer Satisfaction in Financial Services Sector", Managing Service Quality, Vol. 17(3), pp. 259-274.

[7]. Parasurama A., Berry L. L. and Zeithaml V. A. (1991) Refinement and Reassement of the SERVQUAL Scale,.Journal of Retailing, 67.

[8]. Report 26030 (2003) The International Bank for Reconstruction and Development Agriculture \& Rural Development Department 1818 H Street, N.W.

[9]. Zhou, L. (2004), "A Dimension Specific Analysis of Performance Only Measurement of Service Quality and Satisfaction in China's Retail Banking”, Journal of Service Marketing, Vol. 18 (7), pp. 534-546. 